\title{
Citric Acid in Drug Formulations Causes Pain by Potentiating Acid-Sensing Ion Channel 1
}

\author{
Ya Lan Yang ${ }^{1}$ and Ted Weita Lai ${ }^{1,2,3}$ \\ ${ }^{1}$ Graduate Institute of Biomedical Sciences, China Medical University, Taichung 40402, Taiwan , ${ }^{2}$ Drug Development Center, China Medical \\ University, Taichung 40402, Taiwan, and ${ }^{3}$ Translational Medicine Research Center, China Medical University Hospital, Taichung 40402, Taiwan
}

Pain at the injection site is a common complaint of patients receiving therapeutic formulations containing citric acid. Despite the widely acknowledged role of acid-sensing ion channels (ASICs) in acid-related perception, the specific ASIC subtype mediating pain caused by subcutaneous acid injection and the mechanism by which citrate affects this process are less clear. Here, male mice subjected to intraplantar acid injection responded by executing a withdrawal reflex, and this response was abolished by ASIC1 but not ASIC2 knockout. Although intraplantar injection of neutral citrate solution did not produce this response, intraplantar injection of acidic citrate solution produced a withdrawal reflex greater than that produced by acidity alone. Consistent with the behavioral data, neutral citrate failed to produce an electrophysiological response in HEK293 cells, which express ASIC1, but acidic citrate produced a whole-cell inward current greater than that produced by acidity alone. Saturating the intracellular solution with citrate had no effect on the potentiating effect of extracellular citrate, suggesting that citrate acted extracellularly to potentiate ASIC1. Moreover, exposure to citrate immediately before acid stimulation failed to potentiate ASIC1 currents, which ruled out the involvement of a metabotropic receptor gated by a citrate metabolite. Finally, removal of calcium ions from the extracellular solution mimicked the potentiating effect of citrate and prevented citrate from further potentiating ASIC1. Our data demonstrate that ASIC1 is necessary for the nociceptive response caused by subcutaneous acid infusion and that neutral citrate, despite not inducing ASIC1 currents or nociceptive behavior on its own, potentiates acid nociception by removing the inhibitory effect of extracellular calcium ions on ASIC1.

Key words: acid; ASIC; citrate; citric acid; pain; pharmaceutical formulation

Significance Statement

Citric acid is a common ingredient used in pharmaceutical formulations. Despite the widespread clinical use of these formulations, it remains unclear how citric acid causes pain when injected into patients. We identified ASIC1 as the key receptor used to detect injection-site pain caused by acid, and we showed that neutral citrate does not stimulate ASIC1; instead, citrate substantially potentiates ASIC1 activation when injected simultaneously with acid. In addition, we demonstrated that citrate potentiates ASIC1 by removing the inhibitory action of calcium on the extracellular side of the receptor. Given that injectionsite pain is the primary complaint of patients receiving citrate-containing medical products, our data provide mechanistic insight into a common medical complaint and suggest a means of avoiding injection pain.

Received Aug. 8, 2020; revised Dec. 8, 2020; accepted Apr. 10, 2021.

Author contributions: Y.L.Y. and T.W.L. performed research; Y.L.Y. and T.W.L. analyzed data; T.W.L. designed research; T.W.L. wrote the paper.

This work was supported by research grants from the China Medical University (CMU109-MF-28), Ministry of Science and Technology (MOST109-2320-B-039-010), the National Health Research Institutes (NHRI-EX11010803NI) and the Drug Development (enter, China Medical University, from the Featured Areas Research Center Program within the framework of the Higher Education Sprout Project by the Ministry of Education in Taiwan.

The authors declare no competing financial interests.

Correspondence should be addressed to Ted Weita Lai at ted.weita@me.com.

https://doi.org/10.1523/JNEUROSCI.2087-20.2021

Copyright @ 2021 Yang and Lai

This is an open-access article distributed under the terms of the Creative Commons Attribution 4.0 International license, which permits unrestricted use, distribution and reproduction in any medium provided that the original work is properly attributed.

\section{Introduction}

Acid causes pain when injected subcutaneously or intramuscularly into human subjects (Steen and Reeh, 1993; Steen et al., 1995; Issberner et al., 1996; Ugawa et al., 2002; Jones et al., 2004), and pharmaceutical formulations containing citrate (10-25 mM), widely used for its $\mathrm{pH}$ buffering, calcium chelating, and antioxidant properties, cause more pain than citrate-free formulations carrying the same therapeutic agents (Frenken et al., 1993; Veys et al., 1998; Yu et al., 1998; Laursen et al., 2006). As a result, pain at the injection site is a major complaint of patients receiving injections of the current best-selling pharmaceutical product adalimumab (Humira, AbbVie), which has a citrate-buffered acidic formulation, $\mathrm{pH} \mathrm{5.2,} \mathrm{for} \mathrm{the} \mathrm{treatment} \mathrm{of} \mathrm{rheumatoid} \mathrm{ar-}$ thritis and Crohn's disease (Furst et al., 2003; Keystone et al., 2004; van de Putte et al., 2004; Nash et al., 2016). To address this 
A

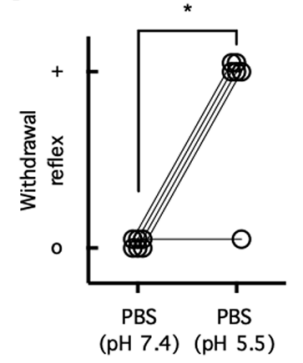

D

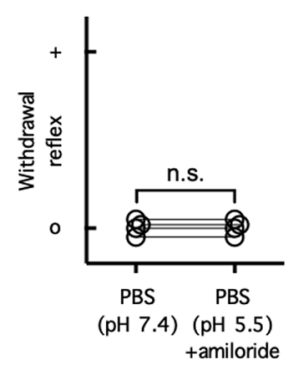

G

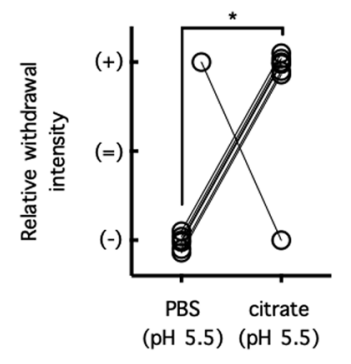

B

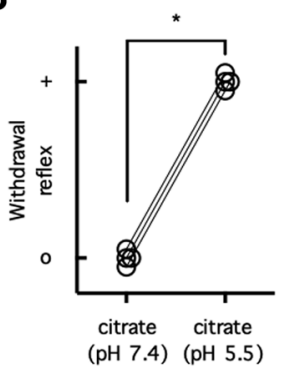

$\mathbf{E}$

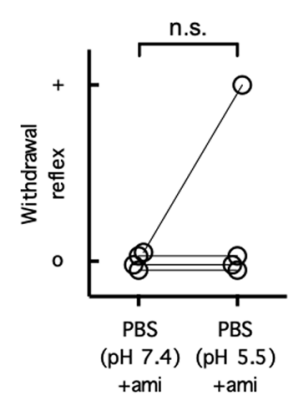

C

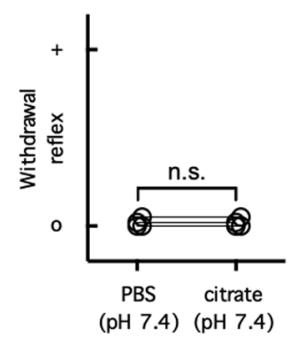

$\mathbf{F}$

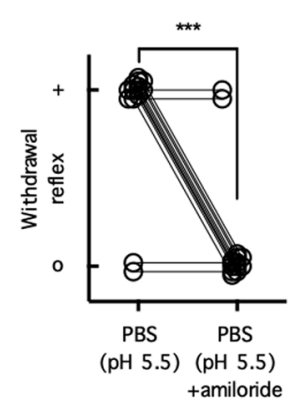

H

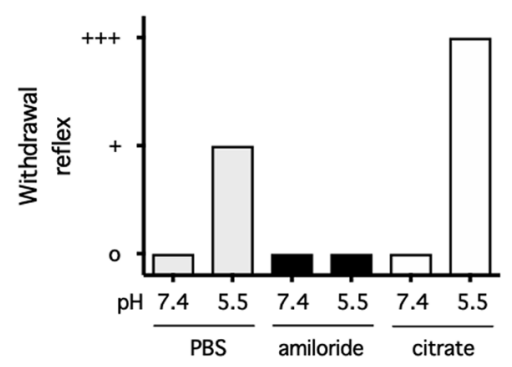

Figure 1. Citrate potentiates ASIC-dependent pain behavior. $\boldsymbol{A}-\boldsymbol{C}$, Each mouse was injected with either PBS, pH $7.4(\boldsymbol{A}, \boldsymbol{C})$, or citrate, pH $7.4(\boldsymbol{B})$ in one hindpaw and then PBS, pH $5.5(\boldsymbol{A})$; or citrate, pH $5.5(B)$; or citrate, pH $7.4(\boldsymbol{C})$, in the other hindpaw, or vice versa. The presence $(+)$ or absence $(0)$ of a withdrawal reflex was recorded; $n=4-6$ per group, n.s. $p>0.05$, $* p<0.05$, two-tailed Mann-Whitney $U$ test, in which $(+)$ was ranked as 1 and $(0)$ was ranked as $0 . \boldsymbol{D}-\boldsymbol{F}$, Each mouse was injected in either hindpaw with PBS, pH 7.4 or 5.5, as described for $\mathbf{A}-\boldsymbol{C}$, with or without amiloride $(100 \mu \mathrm{m})$. The presence $(+)$ or absence $(0)$ of a withdrawal reflex was recorded; $n=4-14$ per group, n.s. $p>0.05$, $* * * p<0.001$, two-tailed Mann-Whitney $U$ test, in which $(+)$ was ranked as 1 and (0) was ranked as 0. G, Each mouse was injected with PBS, pH 5.5, in one hindpaw and then citrate, pH 5.5 ( 25 mm), in the other hindpaw, or vice versa. The relative withdrawal intensity between the two hindpaws was compared and recorded: $(+)$ for greater, $(=)$ for equivalent, and $(-)$ for lesser withdrawal response; $n=7$ per group, $* p<0.05$, two-tailed Mann-Whitney $U$ test, in which $(+)$ was ranked as $+1,(=)$ was ranked as 0 , and $(-)$ was ranked as -1 . $\boldsymbol{H}$, Summary of the results from Figure 1. n.s., Not significant.

unfavorable property, a citrate-free formulation (Humira Citrate-free) recently became commercially available. Moreover, tissue acidosis has been thought to contribute to pain sensation caused by ischemia, inflammation, and surgical incision (Issberner et al., 1996; Benson et al., 1999; Pan et al., 1999; Woo et al., 2004), and citrate levels have been associated with episodes of angina pectoris (Bagger et al., 1981); therefore, understanding the mechanism by which acid or citrate causes pain can have broad clinical implications for understanding pain beyond therapeutic injections. Mammalian cells sense tissue acidification primarily through proton-gated ion channels, including the acidsensing ion channel (ASIC) family (Price et al., 1996; Waldmann et al., 1996, 1997a,b; García-Añoveros et al., 1997) and transient receptor potential cation channel subfamily $\mathrm{V}$ member 1 (TrpV1; Caterina et al., 1997; Tominaga et al., 1998). ASIC is further categorized into subtypes encoded by four separate genes that encode ASIC1a (García-Añoveros et al., 1997; Waldmann et al., 1997a) and its splice variant ASIC1b (Chen et al., 1998; Bässler et al., 2001), ASIC2a (Price et al., 1996; Waldmann et al., 1996; García-Añoveros et al., 1997) and its splice variant ASIC2b (Lingueglia et al., 1997), ASIC3 (Waldmann et al., 1997b), and ASIC4 (Akopian et al., 2000; Gründer et al., 2000); among these

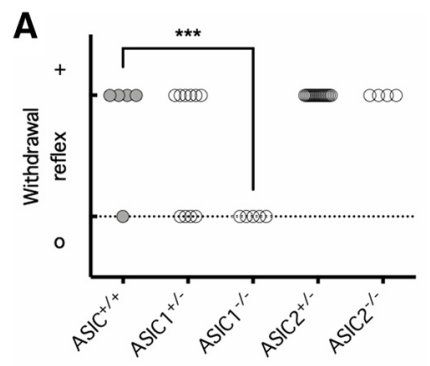

B

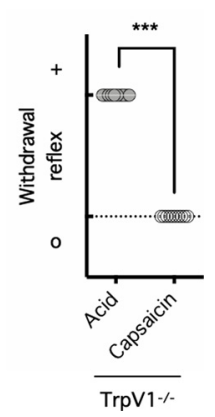

Figure 2. Pain caused by subcutaneous acid is mediated by ASIC1. A, Mice with intact ASIC1 and ASIC2 $\left(\mathrm{ASIC}^{+++}\right)$, hemizygous ASIC1 deletion $\left(A S I C 1^{+/-}\right)$, homozygous ASIC1 deletion $\left(\right.$ ASIC $\left.1^{-1-}\right)$, hemizygous ASIC2 deletion (ASIC2 ${ }^{+1-}$ ), or homozygous ASIC2 deletion $\left(A S I C 2^{-1-}\right.$ ) were injected with PBS, pH 5.5, into one hindpaw. The presence $(+)$ or absence $(0)$ of a withdrawal reflex was recorded; $n=5-17$ per group, $* * * p<0.001$, one-way ANOVA with a post hoc Dunnett's test, in which $(+)$ was ranked as 1 and $(0)$ was ranked as 0. B, Mice lacking TrpV1 $\left(\operatorname{TrpV} 1^{-1-}\right)$ were injected with PBS, pH 5.5, or capsaicin $(1 \mu \mathrm{g})$ into one hindpaw. The presence $(+)$ or absence $(0)$ of a withdrawal reflex was recorded; $n=10$ per group, $* * * p<0.001$, twotailed Mann-Whitney $U$ test, in which $(+)$ was ranked as 1 and $(0)$ was ranked as 0 . 
A
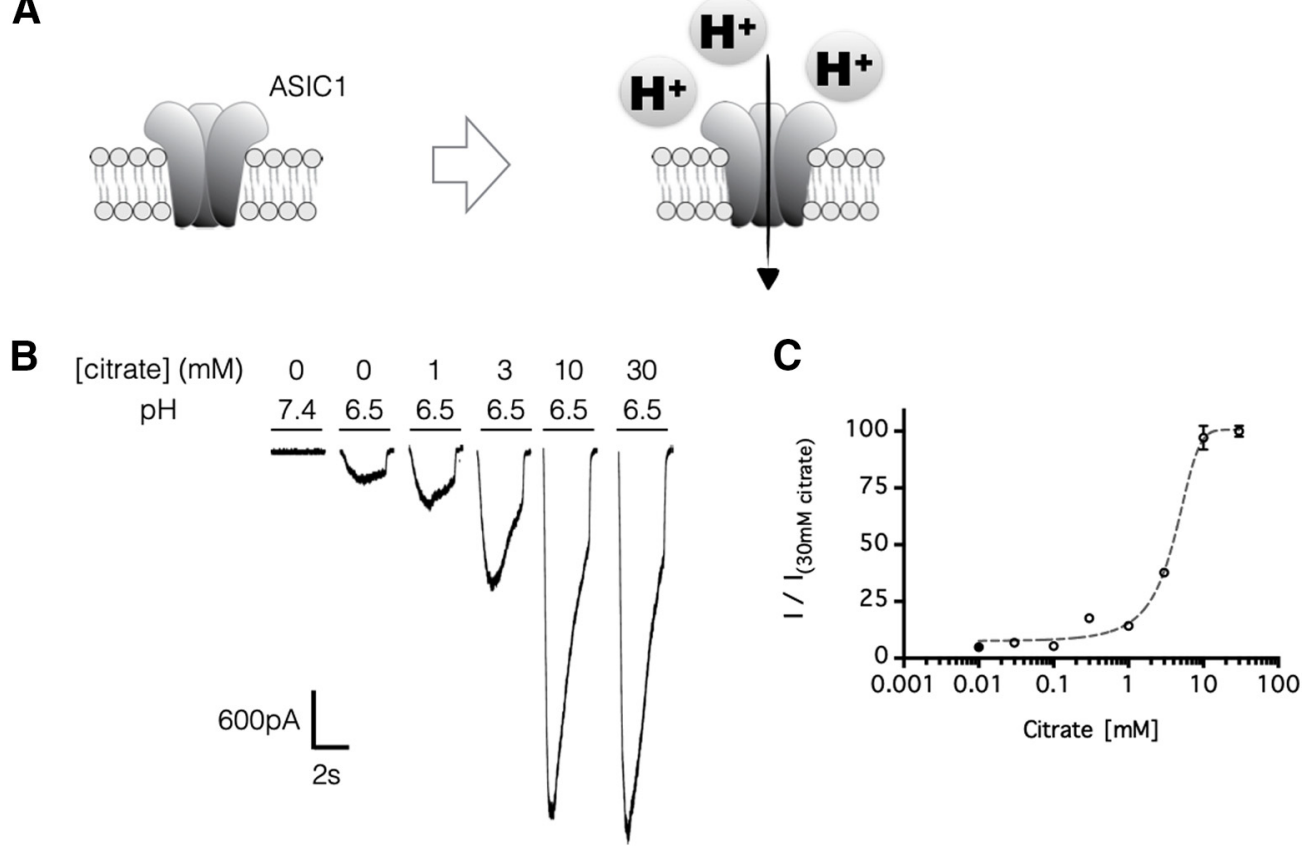

Figure 3. Citrate potentiates ASIC1 currents in a concentration-dependent manner. A, Schematics: ASIC1 generates an inward current in response to increased extracellular protons. $B$, $C$, ASIC1-mediated currents were recorded in HEK293 cells. The cells were perfused in a bath solution, pH 7.4, containing no citrate, and each stimulus consisted of a $3 \mathrm{~s}$ exposure (at $30 \mathrm{~s}$ intervals) to a test solution, pH 6.5, except where pH 7.4 is indicated, that contained $0-30 \mathrm{~mm}$ citrate. In $\mathbf{C}$, all test solutions had a pH of 6.5 , and the concentrations of citrate in the test solutions are indicated on the $x$-axis; $n=4-5$ independent HEK293 cultures, and error bars indicate the mean \pm SEM.

ASIC subtypes, all but ASIC2b and ASIC4 form proton-gated ion channels on their own (Lingueglia et al., 1997; Akopian et al., 2000; Gründer et al., 2000). Although it is widely believed that these proton-gated ion channels, which are expressed on the neurite terminals of nociceptors, are likely initiators of acidrelated sensory transduction, the receptor subtype that mediates acute pain caused by subcutaneous acid injection remains unclear, as does the contribution of citrate to this painful sensation.

In this study, we asked whether neutral citrate at a concentration resembling pharmaceutical products causes acid-like pain when injected subcutaneously in mice and whether it affects pain caused by intraplantar injection of acid at a $\mathrm{pH}$ resembling pharmaceutical products. We found that intraplantar acid injection causes a rapid withdrawal reflex in mice, a response that can be attenuated by coinjection of the ASIC inhibitor amiloride. Although neutral citrate failed to produce such a response, it substantially augmented the nociceptive response caused by the acid injection. To investigate this phenomenon further, we identified ASIC1 as the receptor subtype required for this type of pain perception in vivo, and, in a cell line natively expressing human ASIC1, we further investigated the mechanism by which citrate contributes to acid-induced nociception by studying its pharmacological effect on ASIC1 electrophysiology in vitro.

\section{Materials and Methods}

Mice. Male C57BL/6 mice $(6-7$ weeks old, $20-30 \times \mathrm{g})$ were used in most experiments. Mice lacking ASIC1 (B6.129-Asicl ${ }^{\text {tm } 1 \text { Wsh }} / \mathrm{J}$, stock $\# 013733$; Wemmie et al., 2002), ASIC2 (B6.129-Asic2 ${ }^{\text {tm } 1 \text { Wsh }} / \mathrm{J}$,

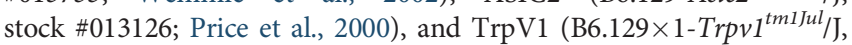
stock \#003770; Caterina et al., 2000) were purchased from The Jackson Laboratory. The mice were provided food and water ad libitum before the experiment, and all experiments involving animals followed the Institutional Guidelines of the China Medical University for the Care and Use of Experimental Animals and were approved by the university's
Institutional Animal Care and Use Committee (Protocol No. 2016-2132 and 2020-401).

Cell culture. HEK293 cells (catalog \#CRL-1573, American Type Culture Collection) were used in the electrophysiological experiments. The cells were cultured in DMEM, supplemented with $10 \%$ fetal bovine serum (FBS) in a $\mathrm{CO}_{2}$ incubator (catalog \#310TS, Thermo Scientific) until used for experiments.

Drugs and chemicals. Sodium citrate tribasic dihydrate and capsaicin were purchased from Sigma-Aldrich (catalog \#S4641 and \#M2028, respectively), amiloride was purchased from Alomone Labs (catalog \#A140), $10 \%$ neutral buffered formalin was purchased from TONYAR BIOTECH. INC. (catalog \#50-00-0), and glacial acetic acid was purchased from J.T.Baker (catalog \#9508-03).

Nociceptive model-withdrawal test. The withdrawal test was designed to assess pain experienced at the moment of subcutaneous injection. To minimize voluntary movements, each mouse was lightly anesthetized by $1.5 \%$ isoflurane (carried by air) induction in a gas chamber, and anesthesia was maintained with a gas mask. This dose of isoflurane sedates the mouse sufficiently to abolish the righting reflex but maintains the mouse's withdrawal reflex in response to a toe pinch. Paired test solutions were injected into opposite hindpaws one at a time ( $10 \mu \mathrm{l} /$ injection), and the relative withdrawal response between each pair of injections was recorded. Specifically, $(+),(=)$, or $(-)$ was recorded when the response in one limb was greater than, equal to, or less than the response in the other limb, respectively. In addition, (o) was recorded when there was no withdrawal response. The order in which each of the paired treatments was injected was initially randomized and then systemically reversed, so each of the paired treatments had an equal chance of being injected first. The investigators performing the experiments were blinded to the treatments. For animals of different genotypes, genotyping was conducted after the completion of the experiments, so the investigators were blind to the genotypes of the animals at the time of the experiment.

Nociceptive models-paw-licking and writhing tests. Conventional nociceptive tests based on formalin-induced paw licking (Hunskaar et al., 1985) and acetic-acid-induced writhing (Witkin et al., 1961; Collier et al., 1968) were additionally used to assess acute chemical-induced pain responses. To assess paw-licking behavior, each mouse received an 
A

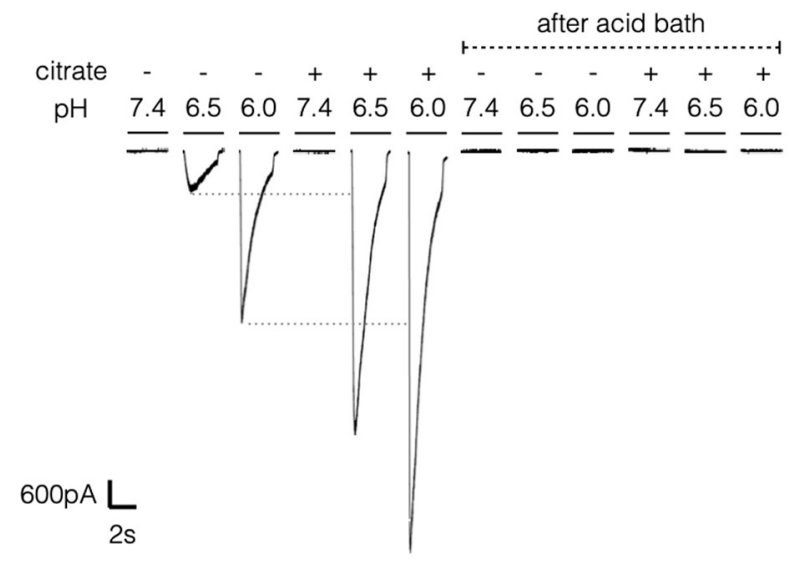

B
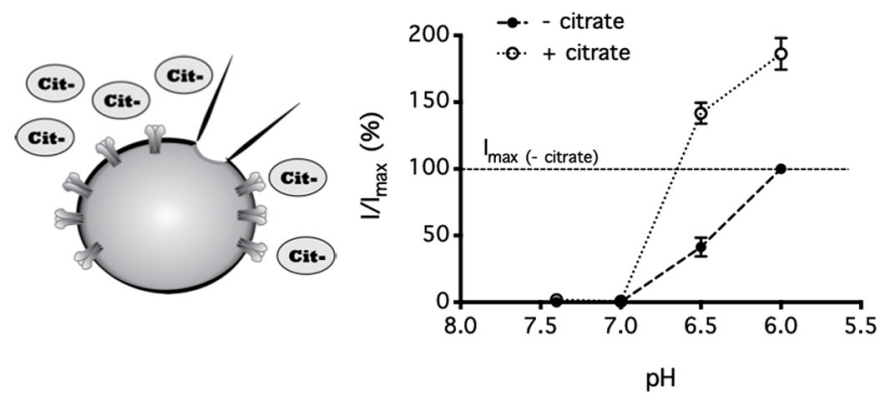

C
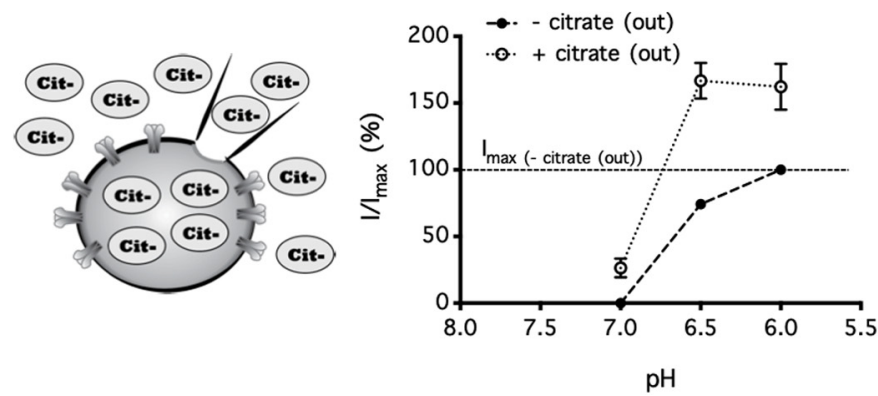

Figure 4. Citrate targets the extracellular site of ASIC1 to potentiate acid-induced currents. $A, B$, Extracellular citrate increased efficacy of ASIC1 currents in HEK293 cells. The cells were perfused in a bath solution, pH 7.4, containing no citrate, and each stimulus consisted of a $3 \mathrm{~s}$ exposure (at $30 \mathrm{~s}$ intervals) to a test solution, $\mathrm{pH}$ 6.0-7.4, with or without citrate (25 mM). In $A$, after changing to an acid bath solution, $\mathrm{pH} 6.5$, inward current can no longer be triggered by the same set of test solutions. In $\boldsymbol{B}$, bath pH was maintained at pH 7.4; $n=6$ independent HEK293 cultures. $\boldsymbol{C}$, Similar to $\boldsymbol{B}$, except that the intracellular solution was preloaded with $25 \mathrm{~mm}$ citrate before recording; $n=8$ independent HEK293 cultures. In $\boldsymbol{B}$ and $\boldsymbol{C}$, error bars indicate the mean \pm SEM.

injection of a test solution into a hindpaw ( $25 \mu \mathrm{l} /$ injection) under brief isoflurane-induced anesthesia, and the duration of its paw-licking behavior was recorded for a period of $30 \mathrm{~min}$. To assess writhing behavior, each mouse received an injection of a test solution into its peritoneal cavity $(10 \mu \mathrm{l} / \mathrm{g})$ under brief isoflurane-induced anesthesia, and the numbers of abdominal contractions or body contortions over a period of $10 \mathrm{~min}$ were recorded. The investigators performing the experiments were blinded to the treatments or animal genotypes.

Electrophysiology-human ASIC1. Whole-cell patch-clamp recording of native human ASIC1 current was performed as previously described (Yang and Lai, 2020). In brief, HEK293 cells were perfused in a bath solution containing the following (in $\mathrm{mm}$ ): $152 \mathrm{NaCl}, 2.5 \mathrm{KCl}, 2$ $\mathrm{CaCl}_{2}, 1 \mathrm{MgCl}_{2}$, and 5 HEPES (the $\mathrm{pH}$ and osmolarity were 7.4 and $300 \pm 10 \mathrm{mOsm}$, respectively) and patched with glass pipettes (tip resistance of 4-6 M $\Omega$ ) filled with intracellular solution (ICS) containing the following (in mM): $10 \mathrm{NaCl}, 120 \mathrm{KCl}, 0.5 \mathrm{CaCl} 2,2 \mathrm{MgCl} 2,5$ EGTA, 10 HEPES, and $2 \mathrm{Mg}$-ATP (the $\mathrm{pH}$ and osmolarity were 7.2 and 310 mOsm, respectively). The membrane potential was held at $-60 \mathrm{mV}$ in all experiments, and each stimulus consisted of a 3 $\mathrm{s}$ switch (at $30 \mathrm{~s}$ intervals) from the bath solution to the test solution, preceded by a voltage step of $-10 \mathrm{mV}$ to detect abrupt changes in membrane capacitance and access resistance. Only one cell was recorded for each independent culture (neighboring cells from the same culture were not recorded), so the sample size represents both the number of independent cultures as well as the number of individual cells recorded.

Electrophysiology-primary sensory neurons. Native ASIC current was recorded from primary sensory neurons collected from dorsal root ganglion (DRG) of isoflurane-anesthetized adult male C57BL/6 mice $(6-7$ weeks old, $20-30 \times \mathrm{g})$. The isolated DRG was kept on ice-cold $\mathrm{Ca}^{2+} / \mathrm{Mg}^{2+}$ free HBSS, dissociated with $0.1 \%$ collagenase and $0.25 \%$ trypsin, and cultured in DMEM/F12 supplemented with $10 \%$ FBS. On the day of recording, the neurons were bathed in extracellular solution, which contained the following (in $\mathrm{mM}$ ): $145 \mathrm{NaCl}, 5 \mathrm{KCl}, 2 \mathrm{MgCl}_{2}, 2 \mathrm{CaCl}_{2}, 10 \mathrm{HEPES}$ (or $10 \mathrm{MES}$ for $\mathrm{pH} 5.5$ ), and was $\mathrm{pH}$ adjusted to 7.4 or 5.5 with $\mathrm{NaOH}$ or $\mathrm{HCl}$, respectively, and patched with glass pipettes (tip resistance of 2-3 M $\Omega$ ) filled with ICS, which contained the following (in $\mathrm{mm}$ ): $10 \mathrm{NaCl}, 120 \mathrm{KCl}, 2 \mathrm{MgCl}_{2}, 0.5 \mathrm{CaCl}_{2}, 5$ EGTA, 10 HEPES, $2 \mathrm{Mg}$-ATP, and its $\mathrm{pH}$ and osmolarity were adjusted to 7.2 with $\mathrm{KOH}$ and 310 mOsm with sucrose, respectively. The membrane potential was held at $-60 \mathrm{mV}$ in all experiments, and each stimulus consisted of a $3 \mathrm{~s}$ switch (at $30 \mathrm{~s}$ intervals) from the bath solution to the test solution and was preceded by a voltage step of $-10 \mathrm{mV}$ to detect abrupt changes in membrane capacitance and access resistance.

Data presentation and analysis. Animal behavior data are shown as individual data points, and cellular electrophysiology data are presented as the mean \pm SEM. Significant differences among groups are noted when the $p$ value is $<0.05$. Nonparametric comparisons of withdrawal reflex intensity between paired injections were made using a two-tailed Mann-Whitney $U$ test, in which a score of $1(+)$ or 0 (o) was assigned for the presence or absence of a response, respectively; additionally, when these comparisons were made between paired injections of test solutions that both consistently produce a response, a score of $1(+), 0(=)$, or $-1(-)$ was assigned when the response in one limb was greater than, equal to, or less than the response in the other limb, respectively. Nonparametric comparisons among multiple groups of animals were made by one-way ANOVA with a post hoc Dunnett's test, in which animals with a response were given a score of 1 $(+)$, and animals without a response were given a score of 0 (o). Parametric comparisons between two means were made by a two-tailed Student's $t$ test, those between multiple means by one-way ANOVA with a post hoc Tukey's multiple comparisons test, and those between multiple means with two matching factors were made by two-way repeated-measures ANOVA with a post hoc Tukey's multiple comparisons test.

\section{Results}

\section{Citrate potentiates but does not induce acid pain}

To determine whether citrate at neutral or acidic $\mathrm{pH}$ produces a nociceptive response at the moment of subcutaneous injection and how this response compares to that produced by PBS-buffered acid solution (PBAS), mice were subjected to intraplantar injections of neutral, $\mathrm{pH} 7.4$, or acidic, $\mathrm{pH}$ 5.5, solutions buffered 
A

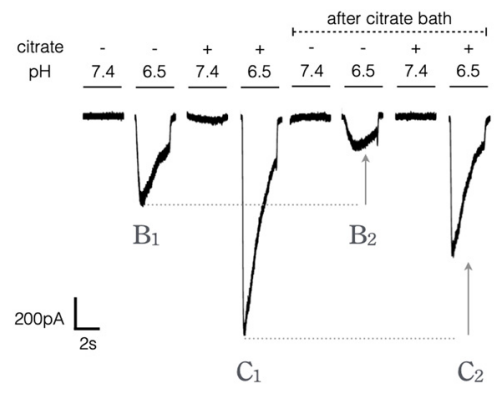

B
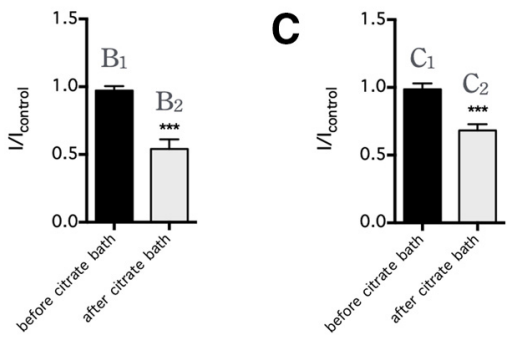

Figure 5. Citrate potentiates ASIC1 current only when applied concurrently with each stimulus. A, HEK293 cells were initially perfused in a bath solution, $\mathrm{pH} 7.4$, without citrate, and each stimulus consisted of a $3 \mathrm{~s}$ exposure (at $30 \mathrm{~s}$ intervals) to a test solution, $\mathrm{pH} 7.4 \mathrm{or}$ 6.5 , with or without citrate $(25 \mathrm{~mm})$. Thereafter, the cells were perfused in a bath solution, $\mathrm{pH} 7.4$, that contained citrate $(25 \mathrm{~mm})$; after the citrate bath, the same set of test solutions now produce smaller inward currents. The result indicates that ASIC1-mediated current was potentiated by the concurrent presence of citrate during the $\mathrm{pH}$ drop $\left(B_{1}\right.$ vs $C_{1}$ or $B_{2}$ vs $\left.C_{2}\right)$ but was depressed (as indicated by arrows) by a preexposure to citrate before the $\mathrm{pH}$ drop ( $B_{1}$ vs $B_{2}$ or $C_{1}$ vs $C_{2}$ ). $B, C$, Summarized results from $A$, comparing current amplitudes of $B_{1}$ to $B_{2}(B)$ and $C_{1}$ to $C_{2}(C)$; error bars indicate the mean \pm SEM; $n=6$ independent HEK293 cultures. $* * * p<0.001$, two-tailed Student's $t$ test.

with PBS or concentrated citrate (25 mm; Fig. $1 A, C)$. PBAS, pH 5.5 , or acidic citrate solution both produced a rapid withdrawal reflex when injected into mice ( $p=0.0152$ for PBS; $p=0.0286$ for citrate; Fig. $1 A, B)$. Consistent with the role of ASICs in this response, the withdrawal reflex triggered by PBAS was mitigated when the broad-spectrum ASIC inhibitor amiloride was coadministered (PBAS with amiloride $p>0.9999$ compared with neutral PBS; $p>0.9999$ compared with neutral PBS with amiloride; $p=0.0004$ compared with PBAS alone; Fig. $1 D-F)$. As a negative control, injection of neutral PBS did not produce the rapid withdrawal reflex mentioned above (Fig. 1A,C). Somewhat unexpectedly, however, injection of concentrated citrate $(25 \mathrm{~mm})$ at a neutral $\mathrm{pH}$ value, $\mathrm{pH} 7.4$, also did not produce this nociceptive response ( $p>0.9999$ compared with neutral PBS; Fig. 1C). To compare the relative pain intensity triggered by PBAS, $\mathrm{pH} 5.5$, versus acidic citrate, $\mathrm{pH} 5.5$, mice were subjected to intraplantar injections of either solution into one hindpaw followed by the other solution into the other hindpaw (Fig. $1 G$ ). Although neutral citrate, $\mathrm{pH} 7.4$, did not cause an acid pain response, the nociceptive response produced by acidic citrate, $\mathrm{pH}$ 5.5, was consistently much more intense than that induced by PBAS $(p=0.0291$, pH 5.5; Fig. $1 G)$. These data altogether suggest that although citrate per se does not induce ASIC-mediated pain, it strongly potentiates ASIC-mediated pain caused by an acidic stimulus (Fig. 1H).

ASIC1 is the key receptor subtype involved in acute acid pain There is now ample evidence that the ASIC family of excitatory ion channels is required for acute and chronic acid-related pain, but it is less clear which ASIC subtype is required for which type of acid-related pain. Given the agonistic effect of amiloride on
ASIC3 (Yagi et al., 2006; Li et al., 2011) and the lack of nociceptive response on amiloride injection at neutral $\mathrm{pH}$ (Fig. 1E), we reasoned that ASIC3 is unlikely to be the receptor subtype for PBAS-induced withdrawal reflex. On the other hand, given the antagonistic effect of amiloride on ASIC1 and ASIC2 and the inhibition of the PBAS-induced withdrawal reflex by amiloride (Fig. 1D-F), we next asked whether either ASIC1, ASIC2, or both might be involved in this nociceptive response. To investigate this possibility, mice partially or completely lacking ASIC1 $\left(\mathrm{ASIC1}^{+/-} ; \mathrm{ASIC1}^{-/-}\right)$or ASIC2 $\left(\mathrm{ASIC2}^{+-} ; \mathrm{ASIC2}^{-/-}\right)$or control mice with intact $A S I C 1$ and 2 receptors $\left(A S I C^{+/+}\right)$were subjected to intraplantar injections of PBAS, pH 5.5 (Fig. 2A). Impressively, $A S I C 1^{-1-}$ mice consistently failed to demonstrate any acute nociceptive response on intraplantar PBAS injection $\left(p=0.5250\right.$ for $A S I C 1^{+/-}$mice and $p=0.0005$ for $A S I C 1^{-1-}$ mice, compared with $A S I C^{+/+}$mice; Fig. $2 A$ ). In marked contrast, $A S I C 2^{+/-}$and $A S I C 2^{-/-}$mice consistently demonstrated an intact nociceptive response on intraplantar PBAS injection ( $p=0.4639$ for $A S I C 2^{+/-}$mice and $p=0.6801$ for $A S I C 2^{-1-}$ mice, compared with $A S I C^{+/+}$mice; Fig. $2 A$ ). In line with early evidence that ASIC is solely responsible for subcutaneous pain caused by mild acidity, whereas both ASIC and TrpV1 contribute to subcutaneous pain caused by severe acidity (Ugawa et al., 2002), mice lacking TrpV1 $\left(\operatorname{Trp} V 1^{-1-}\right)$ demonstrated an intact nociceptive response on intraplantar injection of PBAS, which mimicked pharmaceutical formulations to be only mildly acidic, $\mathrm{pH} 5.5$, but not on intraplantar injection of TrpV1 agonist capsaicin $(p<0.0001$; Fig. $2 B)$. These data demonstrate that ASIC1 and not ASIC2 is the receptor subtype mediating the pain that triggers the withdrawal reflex on intraplantar acid injection.

\section{Citrate potentiates but does not stimulate ASIC1}

The lack of a PBAS-induced withdrawal reflex with amiloridemediated inhibition (Fig. $1 E-G$ ) or ASIC1 gene knockout (Fig. $2 A$ ) suggested that acute pain caused by intraplantar acid injection was mediated by ASIC1. Nevertheless, this finding did not explain how citrate could potentiate ASIC1-mediated pain behavior (Fig. 1H). To examine this further, we investigated the pharmacological effect of citrate on the electrophysiological properties of ASIC1 (Fig. 3A). We previously reported that HEK293 cells express native human ASIC1a and ASIC1b homologues at proportions similar to what is found in human primary sensory neurons, making this cell line suitable for studying the electrophysiology of ASIC1-mediated pain (Yang and Lai, 2020). Here, in line with the potentiating effect of citrate on ASICmediated nociceptive behavior, citrate (1-30 mM) markedly potentiated HEK293 ASIC1 currents in a concentration-dependent manner, with an $\mathrm{EC}_{50}$ of 3-5 mm (Fig. 3B,C). Moreover, consistent with the in vivo data showing that citrate at neutral $\mathrm{pH}$ did not induce ASIC-mediated pain (Fig. $1 B, C$ ), citrate at $\mathrm{pH} 7.4$ did not induce any inward current in HEK293 cells (Fig. 4A,B). Therefore, our data demonstrated that citrate markedly increases the efficacy (maximum response) but has little or no effect on the potency $\left(\mathrm{EC}_{50}\right)$ of $\mathrm{ASIC1}$ channels in vitro (Fig. $4 A, B$ ), which corresponds to its effect on pain behavior in vivo.

Knowing that citrate alone did not activate ASIC1 (Fig. 4A, $B)$, we next conducted experiments to investigate how citrate potentiated ASIC1 currents. First, preloading the cells with an equal concentration of intracellular citrate did not prevent the potentiation of ASIC1 current by extracellularly applied citrate (Fig. 4C), demonstrating that citrate exerted its effect by acting on the extracellular rather than the intracellular domain of ASIC1. Second, citrate depressed rather than potentiated ASIC1 

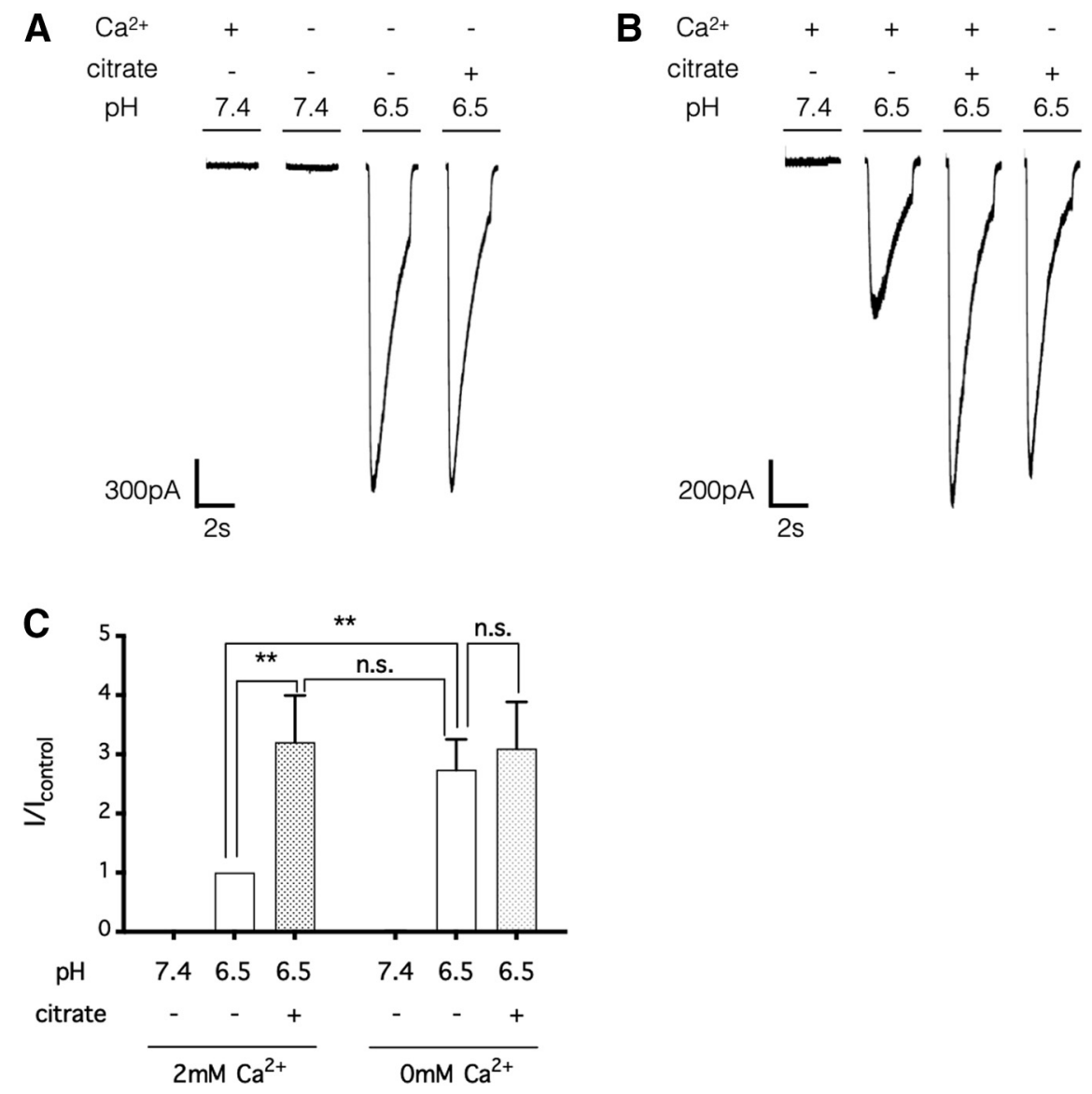

Figure 6. Citrate potentiates the ASIC1 current by chelating extracellular calcium ions. A, B, HEK293 cells were perfused in a bath solution, $\mathrm{pH}^{7.4}$, containing $2 \mathrm{~mm} \mathrm{Ca}^{2+}$ and no citrate, and each stimulus consisted of a $3 \mathrm{~s}$ exposure (at $30 \mathrm{~s}$ intervals) to a test solution, $\mathrm{pH} 7.4$ or 6.5 , with or without citrate $(25 \mathrm{~mm})$ and/or $\mathrm{Ca}^{2+}$ ( 2 mM). The results indicate that citrate failed to potentiate the ASIC1-mediated current triggered by a $\mathrm{Ca}^{2+}$-free test solution, $\mathrm{pH} 6.5(\mathrm{~A})$, and that $\mathrm{Ca}^{2+}$ removal failed to further potentiate the ASIC1-mediated current triggered by a test solution containing citrate $(25 \mathrm{~mm} ; \boldsymbol{B})$. C, Summarized results from $\boldsymbol{A}$ and $\boldsymbol{B}$; error bars indicate the mean \pm SEM; $n=5$ independent HEK293 cultures; n.s. $p>0.05$, $* * p<0.01$, two-way repeated measures analysis of variance (matching recordings from the same cell) with a post hoc Tukey's test. n.s., Not significant.

currents when administered before rather than concurrently with acidic $\mathrm{pH}(p=0.0002$ for acid stimuli after bath exposure to neutral citrate, $p=0.0008$ for acidic citrate stimuli after bath exposure to neutral citrate; Fig. $5 A-C$ ). Thus, the effect of extracellular citrate on ASIC1 was likely direct, rather than requiring an intermediate second messenger generated, for instance, from metabotropic receptors gated by citrate analogs (He et al., 2004). Third, removal of $\mathrm{Ca}^{2+}$, a known inhibitor of ASIC1 (Paukert et al., 2004; Zhang et al., 2006; Zuo et al., 2018), from the extracellular solution also potentiated ASIC1 currents in HEK cells $(p<0.01$, compared with acid stimuli in $\mathrm{Ca}^{2+}$-intact extracellular solution), and in this situation, citrate failed to further potentiate the response $(p>0.05$, compared with acid stimuli in $\mathrm{Ca}^{2+}$-free extracellular solution; Fig. 6A-C). Together, our electrophysiological data demonstrated that concurrent citrate treatment potentiated ASIC1 by chelation of $\mathrm{Ca}^{2+}$ from the extracellular domain of the ion channel.

\section{Citrate also potentiates ASIC subtypes not required for subcutaneous acid pain}

The primary sensory neurons express many different acid-sensitive receptors and ion channels, with many possible subunit combinations. Complementary to our data showing that ASIC1 but not ASIC2 subunit of the ASIC family is required for pain caused by subcutaneous injection of acid (at a $\mathrm{pH}$ relevant for pharmaceutical formulations; Fig. 2A), previous studies have noted the involvement of other ASIC subtypes of the primary sensory neurons in other types of sensory perceptions and/or physiological responses (Price et al., 2000, 2001; Lin et al., 2016). Therefore, we next ask whether citrate potentiates ASIC natively expressed by primary sensory neurons in wild-type mice with intact pain perception and/or in $A S I C 1^{-/-}$mice lacking subcutaneous acid pain perception (Fig. $7 A-D)$. As with ASIC1 expressed in HEK cells, citrate potentiated amiloride-sensitive acid current in primary sensory neurons isolated from wild-type mouse dorsal root ganglia ( $p=0.0074$, for comparison of acid current with or without citrate; $p=0.0059$, for comparison of acid current with or without amiloride; (Fig. $7 A, B$ ). Notably, in primary sensory neurons from $A S I C 1^{-1-}$ mice, citrate also potentiated amiloride-sensitive acid current $(p=0.0097$, for comparison of acid current with or without citrate; $p=0.0090$, for comparison of acid current with or without amiloride; Fig. 7C). Likewise, in primary sensory neurons from $A S I C 2^{-1-}$ mice, citrate potentiated amiloride-sensitive acid current ( $p<0.0001$, for comparison of acid current with or without citrate; $p<0.0001$, for comparison of acid current with or without amiloride; Fig. 7D). Together, our data suggest that citrate can potentiate ASIC subtypes involved in other sensory modalities or physiological responses in addition to its effect on pain perception mediated by ASIC1.

\section{ASIC1 is not required for acid-induced paw-licking and writhing responses}

Among the conventional rodent models of nociception, the formalin-induced paw-licking test and the acetic-acid-induced 
writhing test are the most widely used for assessing chemical-induced acute pain (Le Bars et al., 2001; González-Cano et al., 2020). Therefore, we also assessed pain responses caused by citric acid in these models and examined whether these responses are also ASIC1 dependent. In the pawlicking test, injection of $5 \%$ formalin into a hindpaw readily caused a paw-licking response lasting over $100 \mathrm{~s}$ in duration (Fig. 8A). Although injection of citric acid resembling the concentration (30 $\mathrm{mm}$ ) and $\mathrm{pH} 5.5$ used in pharmaceutical formulations failed to produce an appreciable pawlicking response, a higher dose of citric acid (100 $\mathrm{mm}$ ) at a lower $\mathrm{pH}$ of 3.5 produced a paw-licking response similar in duration to $5 \%$ formalin $(p<0.0001$, compared with $30 \mathrm{~mm}$ or $100 \mathrm{~mm}$ citric acid at $\mathrm{pH} 5.5 ; p=0.9961$, compared with $5 \%$ formalin; Fig. $8 A$ ). Unlike the ASIC1-dependency of acid-mediated withdrawal reflex (Fig. 2), paw-licking responses induced by either $5 \%$ formalin or $100 \mathrm{~mm}$ citric acid, $\mathrm{pH} 3.5$, could not be hindered by amiloride ( $p=0.9483$ for formalin, $p=0.8607$ for citric acid; Fig. $8 B, C$ ), and pawlicking response induced by $100 \mathrm{~mm}$ citric acid, $\mathrm{pH} 3.5$, remained intact in $A S I C 1^{-1-}$ mice $(p=0.7904$ compared with wild-type mice; Fig. $8 D)$. In the writhing test, intraperitoneal injection of $1 \%$ acetic acid at $\mathrm{pH} 3.5$ readily induced episodes of abdominal contraction $(p<0.0001$, compared with 30 or $100 \mathrm{~mm}$ citric acid) and body contortion $(p<0.0001$, compared with 30 or $100 \mathrm{~mm}$ citric acid), whereas intraperitoneal injection of $30 \mathrm{~mm}$ citric acid, $\mathrm{pH} 5.5$, induced no writhing response, and $100 \mathrm{~mm}$ citric acid, $\mathrm{pH}$ 3.5 , induced little abdominal contractions and no body contortion (Fig. 9A,B). Given previously reported data showing that acetylcholine-mediated writhing response is cholinergic receptor dependent (Collier et al., 1968) and our data showing that acidinduced withdrawal response is ASIC1 dependent (Fig. 2A), we next assessed whether acetic-acid-mediated writhing response is also ASIC1 dependent. In contrast to acid-induced withdrawal reflex, acetic-acid-mediated abdominal contraction and body contortion could not be inhibited by amiloride ( $p=0.1209$ for abdominal contraction, $p=0.2123$ for contortion; Fig. $9 C, D)$ and remained intact in $A S I C 1^{-l-}$ mice $(p=0.9294$ for abdominal contraction, $p=0.2598$ for contortion; Fig. $9 E, F)$. In summary, citric acid, at a concentration and $\mathrm{pH}$ typically used in pharmaceutical formulations, failed to produce a noticeable response in the two conventional rodent models of nociception. Interestingly, although a higher concentration and lower $\mathrm{pH}$ of citric acid produced paw-licking responses, and acetic acid produced writhing responses, these acid pain responses were ASIC1 independent.

\section{Discussion}

Early evidence from experiments with human subjects demonstrates that the pain caused by direct infusion of acidic solution can be attenuated by the broad-spectrum ASIC inhibitor amiloride (Ugawa et al., 2002; Jones et al., 2004). To investigate this further, we studied the nociceptive response of mice subjected to intraplantar injection of acidic solutions. As in the aforementioned experiments conducted in human subjects, the nociceptive response caused by intraplantar injection of mildly acidic PBAS in mice was attenuated by amiloride, consistent with the notion that ASICs play a role in this process. Because the physiological functions of different ASIC subtypes are best characterized in mice lacking these receptors, we next repeated the same experiments using $A S I C 1^{-1-}$ and $A S I C 2^{-/-}$mice. Previous studies reported in the literature have shown that $A S I C 1^{-1-}$ mice are born with impaired hippocampal synaptic plasticity and spatial memory (Wemmie et al., 2002; but see Wu et al., 2013), impaired fear expression and memory (Wemmie et al., 2003; Coryell et al., 2008; Ziemann et al., 2009), exacerbated seizure vulnerability (Ziemann et al., 2008), and mitigated susceptibility to ischemic and inflammatory brain injury (Xiong et al., 2004; Friese et al., 2007; Duan et al., 2011). Additionally, it has been shown that $A S I C 2^{-1-}$ mice have impaired rapidly adapting mechanical sensation (Price et al., 2000; but see Roza et al., 2004), a normal hearing threshold coupled with increased susceptibility to noise (Peng et al., 2004; Roza et al., 2004), and enhanced visual signal transduction and increased susceptibility to light-induced retinal injury (Ettaiche et al., 2004), and the hippocampal neurons of these mice are shown to have reduced numbers of dendritic spines in the CA1 region (Zha et al., 2009). In the present study, we further demonstrated that the nociceptive response caused by intraplantar acid injection was lost in 
A
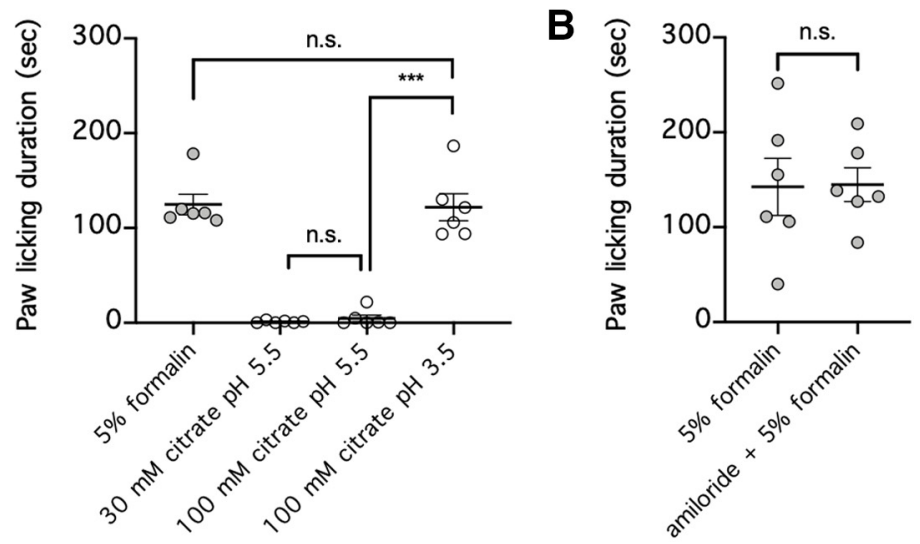

C

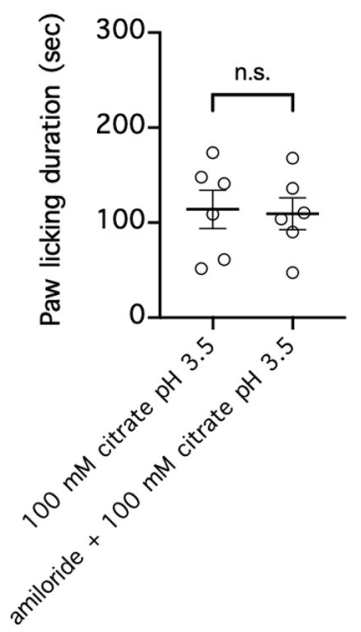

D

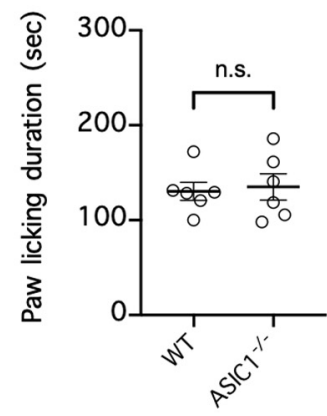

Figure 8. Concentrated citric acid at pH 3.5 but not at pH 5.5 induces paw-licking behavior that is ASIC1 independent. $A$, Each mouse was injected with either $5 \%$ formalin; $30 \mathrm{~mm}$ citrate, pH 5.5; or $100 \mathrm{~mm}$ citrate, pH 5.5 or 3.5 , into one hindpaw, and the duration of paw licking over a period of 30 min was recorded; $n=6$ per group, n.s. $p>0.05, * * * p<0.001$, one-way ANOVA with a post hoc Tukey's test. $\boldsymbol{B}, \boldsymbol{C}$, Each mouse was injected with either $5 \%$ formalin, with or without amiloride $(100 \mu \mathrm{m} ; \boldsymbol{B})$ or $100 \mathrm{~mm}$ citrate, $\mathrm{pH} 3.5$, with or without amiloride (100 $\mu \mathrm{m} ; C)$ into one hindpaw, and the duration of paw licking over a period of $30 \mathrm{~min}$ was recorded; $n=6$ per group, n.s. $p>0.05$, two-tailed Student's $t$ test. $\boldsymbol{D}$, wild-type mice (WT) or mice with homozygous ASIC1 deletion (ASIC ${ }^{-1-}$ ) were injected with $100 \mathrm{~mm}$ citrate, pH 3.5, into one hindpaw, and the duration of paw licking over a period of 30 min was recorded; $n=6$ per group, n.s. $p>0.05$, twotailed Student's $t$ test. n.s., Not significant.

$\mathrm{ASIC1}^{-/-}$but not $\mathrm{ASIC} 2^{-1-}$ mice, suggesting that ASIC1 mediates this response. Notably, ASIC3 was not examined in our study because (1) amiloride, which attenuated the nociceptive response in this study, has been shown to activate ASIC3 at neutral $\mathrm{pH}$ and potentiate ASIC3 at mildly acidic $\mathrm{pH}$ (Yagi et al., 2006; Li et al., 2011), and (2) ASIC ${ }^{-1-}$ mice, although somewhat resistant to some forms of chronic pain, are previously reported to have increased rather than reduced sensitivity to different forms of acute pain (Chen et al., 2002).

In addition to the ASIC1-mediated acute pain caused by subcutaneous acid injection as reported in this study, there is now ample evidence that ASIC subtypes contribute to different types of pain. $A S I C 3^{-1-}$ mice but not $A S I C 1^{-1-}$ mice have reduced vulnerability to acid-induced mechanical hypersensitivity (Price et al., 2001; Sluka et al., 2003) and serotonin-induced acid hypersensitivity (Wang et al., 2013). Following carrageenan-induced muscle inflammation, $\mathrm{ASIC1}^{-1-}$ mice have impaired primary mechanical hyperalgesia and intact secondary mechanical hyperalgesia (Walder et al., 2010), whereas $A S I C 3^{-1-}$ mice have intact primary mechanical hyperalgesia but impaired secondary mechanical hyperalgesia (Sluka et al., 2007; Ikeuchi et al., 2008; Yen et al., 2009; Walder et al., 2010). As mentioned earlier, rather than having acute sensory impairment, $A S I C 3^{-1-}$ mice are found to have increased sensitivity to acute pain caused by acetic acid, heat, and mechanical force (Chen et al., 2002); in comparison, $A S I C 1^{-1-}$ and $A S I C 2^{-1-}$ mice, but not $\mathrm{ASIC}^{-1-}$ and $\operatorname{TrpV} 1^{-1-}$ mice, have increased sensitivity to acute pain caused by formalin injection (Staniland and McMahon, 2009). Overall, the availability of ASIC knock-out mice has made it possible to delineate the role of each receptor subtype in pain perception and other physiological processes.

Although the past two decades witnessed the discovery of animal toxins that can inhibit ASIC subtypes with greater specificity than amiloride, these toxins generally inhibit more than one combination of ASIC subunits, and their pharmacological properties may be different from those initially observed. For example, the tarantula toxin psalmotoxin-1 (PcTx1) was initially thought to be a specific inhibitor of ASIC1a homomeric receptors (Escoubas et al., 2000), but later studies found that this toxin also inhibits heteromeric receptors composed of ASIC1a/ ASIC2a or ASIC1a/ASIC2b (Sherwood et al., 2011; Joeres et al., 2016; Liu et al., 2018). The black mamba venom peptide mambalgin-1 inhibits receptors composed of a large number of ASIC subunit combinations, including homomeric receptors composed of ASIC1a or ASIC1b and heteromeric receptors composed of ASIC1a/ASIC1b, ASIC1a/ASIC2a, and ASIC1a/ASIC2b but has no effect on homomeric receptors composed of ASIC2a or ASIC3 or heteromeric receptors composed of ASIC1a/ASIC3 or ASIC1b/ASIC3 (Diochot et al., 2012). The sea anemone peptide APETx2 was initially thought to be a specific inhibitor of homomeric receptors composed of ASIC3 and heteromeric receptors composed of ASIC1a/ASIC3 and ASIC1b/ASIC3 but has no effect on homomeric receptors composed of ASIC1a, ASIC1b, or ASIC2a or heteromeric receptors composed of ASIC2a/ASIC3 (Diochot et al., 2004). However, more recent evidence demonstrates that this toxin, at a concentration used in previous in vivo animal experiments, also inhibits $\mathrm{Na}_{\mathrm{v}} 1.8$, required for signal transduction by primary sensory neurons (Blanchard et al., 2012). This raised the intriguing possibility that the analgesic properties seen with APETx2 may be partly, if not completely, unrelated to its inhibition of ASIC. Therefore, caution needs to be taken when interpreting experimental results based solely on pharmacological agents that inhibit ASIC.

In contrast to protons, citric acid is a small organic acid molecule with distinct $\mathrm{pK}_{\mathrm{a}}$ values for each of its three carboxylic acid groups; this and other chemical properties have made citric acid a widely used chemical ingredient in many pharmaceutical formulations (Chalgeri and Tan, 1993; Pygall et al., 2009). Indeed, adalimumab (Humira, AbbVie), one of the best-selling pharmaceutical products, had a citrate-buffered acidic formulation, $\mathrm{pH}$ 5.2. Like other citrate-containing pharmaceutical products (Frenken et al., 1993; Veys et al., 1998; Yu et al., 1998; Laursen et al., 2006), however, pain at the site of injection was a major complaint of patients receiving injections of adalimumab for the 
treatment of rheumatoid arthritis and Crohn's disease (Furst et al., 2003; Keystone et al., 2004; van de Putte et al., 2004; Nash et al., 2016). In this study, we found that neutral citrate alone does not cause the nociceptive response seen in mice treated with intraplantar acid injection, but it dramatically potentiates the response when injected simultaneously with acid. To examine this further, we studied the pharmacological action of citrate on HEK cells, which natively expressed human ASIC1, with an ASIC1a-toASIC1b transcription ratio similar to that of human primary sensory neurons but not ASIC2 or ASIC3 (Gunthorpe et al., 2001; Yang and Lai, 2020). As in the behavioral data, we found that citrate alone does not activate ASIC1 but strongly potentiates ASIC1-mediated inward current when applied concurrently with acid. Finally, we found that citrate (1) acted extracellularly rather than intracellularly to produce this effect, (2) needs to be present concurrently with acidity to have this effect, and (3) produces this effect chiefly by chelating extracellular $\mathrm{Ca}^{2+}$.

Our data on the potentiating effect of citrate-mediated $\mathrm{Ca}^{2+}$ removal on acid-mediated response is consistent with the known physiological role of $\mathrm{Ca}^{2+}$ on the electrophysiology of ASIC1 and other ion channels of the ASIC family. In particular, $\mathrm{Ca}^{2+}$ is thought to be a constitutive open-channel blocker that keeps ASIC3 in the closed state at neutral $\mathrm{pH}$, and when there is a decrease in extracellular $\mathrm{pH}$, protonation of key amino acid residues on the ion channel relieves the channel pore of $\mathrm{Ca}^{2+}$ blockade to cause channel opening (Immke and McCleskey, 2003). This model is supported by the finding that removal of extracellular $\mathrm{Ca}^{2+}$ sufficiently opens the ASIC3 ion channel without a change in $\mathrm{pH}$ (Immke and McCleskey, 2003). In comparison, although $\mathrm{Ca}^{2+}$ also modulates the activities of ASIC1a and ASIC1b (Babini et al., 2002; Paukert et al., 2004; Zhang et al., 2006), removal of $\mathrm{Ca}^{2+}$ does not efficaciously activate these ion channels without a change in pH (Paukert et al., 2004). Additionally, a recent study found the key amino acid residue required for $\mathrm{Ca}^{2+}$-binding to rat ASIC3 and showed that mutation of this residue hindered ASIC3 activation induced by $\mathrm{Ca}^{2+}$ removal (Zuo et al., 2018); interestingly, the reverse substitution of the equivalent residue on chicken ASIC1 made the ion channel sensitive to activation induced by $\mathrm{Ca}^{2+}$ removal (Zuo et al., 2018). Based on the known dissociation constant of $\mathrm{Ca}^{2+}$-bound citric acid (6.0-7.0 × 10 $0^{-4} \mathrm{M}$; Greenwald, 1938; Joseph, 1946; Walser, $1961)$, the concentration of free $\mathrm{Ca}^{2+}$ in the test solutions used in our electrophysiology experiments would be within the ranges of $42-49 \mu \mathrm{M}, 50-60 \mu \mathrm{M}, 140-160 \mu \mathrm{M}, 560-610 \mu \mathrm{M}$, and 1.31-1.34 mm for solutions that contained 30, 25, 10, 3, and $1 \mathrm{~mm}$ citrate, respectively. Therefore, given that free $\mathrm{Ca}^{2+}$ at a concentration of $100 \mu \mathrm{M}$ or less has no inhibitory effect on ASIC1 efficacy (Paukert et al., 2004), our test solutions that contained 25 or $30 \mathrm{~mm}$ citrate would essentially remove any inhibitory effect of $\mathrm{Ca}^{2+}$ on ASIC1.
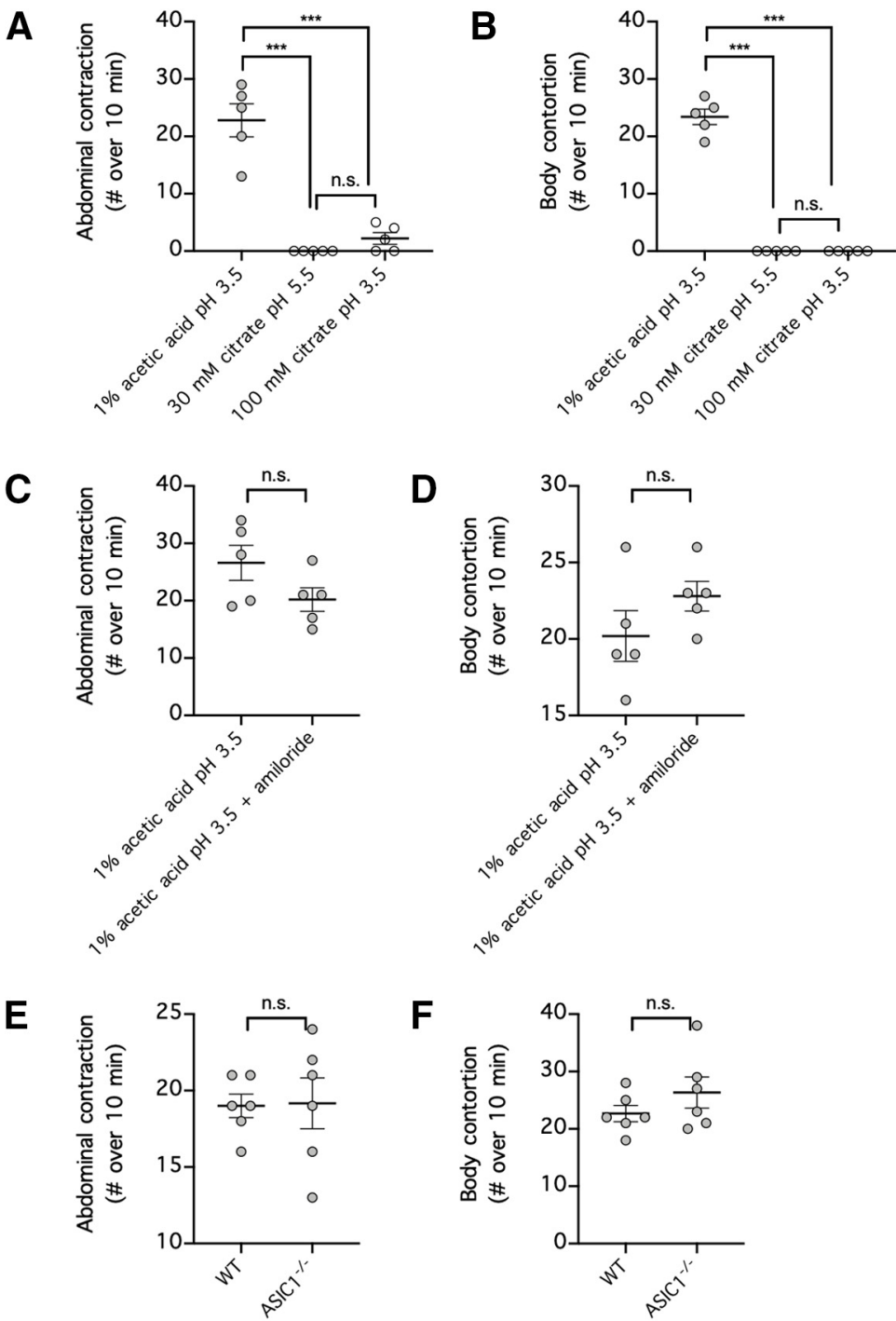

Figure 9. Acetic acid but not citric acid induces writhing behavior that is ASIC1 independent. $\boldsymbol{A}, \boldsymbol{B}$, Each mouse received intraperitoneal injection of either $1 \%$ acetic acid, $\mathrm{pH} 3.5 ; 30 \mathrm{~mm}$ citric acid, $\mathrm{pH}$ 5.5; or $100 \mathrm{~mm}$ citric acid, $\mathrm{pH}$ group, n.s. $p>0.05$, two-tailed Student's $t$ test. $\boldsymbol{E}, \boldsymbol{F}$, wild-type mice (WT) or mice with homozygous ASIC1 deletion $A S I C 1^{-1-}$ ) received intraperitoneal injection of $1 \%$ acetic acid, $\mathrm{pH} 3.5$, and the numbers of abdominal contractions $(\boldsymbol{E})$ and body contortions $(\boldsymbol{F})$ over a period of $10 \mathrm{~min}$ were recorded; $n=6$ per group, n.s. $p>0.05$, two-tailed Student's $t$ test. n.S., Not significant.

In conclusion, we show in this study how citric acid causes pain by stimulating and potentiating ASIC1. The acid component of citric acid is required for ASIC1 stimulation, and the citrate component, although on its own does not activate ASIC1, strongly potentiates acid-induced ASIC1 activation by chelating extracellular $\mathrm{Ca}^{2+}$ that normally inhibits the receptor. This explains why injections of some pharmaceutical products are so painful when their formulations are only mildly acidic. Although pharmaceutical products can sometimes be reformulated without citrate (as has been the case of Humira Citrate-free), this might not always be a feasible or cost-effective option. To avoid painful injections without the need to eliminate citrate from drug formulations, it might be possible to formulate therapeutic agents with inhibitors of ASIC1 or with supplemented $\mathrm{Ca}^{2+}$ ions to saturate ASIC1 in the presence of citrate. 


\section{References}

Akopian AN, Chen CC, Ding Y, Cesare P, Wood JN (2000) A new member of the acid-sensing ion channel family. Neuroreport 11:2217-2222.

Babini E, Paukert M, Geisler HS, Grunder S (2002) Alternative splicing and interaction with di- and polyvalent cations control the dynamic range of acid-sensing ion channel 1 (ASIC1). J Biol Chem 277:41597-41603.

Bagger JP, Toftegaard Nielsen T, Henningsen P, Thomsen PE, Eyjolfsson K (1981) Myocardial release of citrate and lactate during atrial pacinginduced angina pectoris. Scand J Clin Lab Invest 41:431-439.

Bässler EL, Ngo-Anh TJ, Geisler HS, Ruppersberg JP, Gründer S (2001) Molecular and functional characterization of acid-sensing ion channel (ASIC) 1b. J Biol Chem 276:33782-33787.

Benson CJ, Eckert SP, McCleskey EW (1999) Acid-evoked currents in cardiac sensory neurons: a possible mediator of myocardial ischemic sensation. Circulation research 84:921-928.

Blanchard MG, Rash LD, Kellenberger S (2012) Inhibition of voltage-gated $\mathrm{Na}(+)$ currents in sensory neurones by the sea anemone toxin APETx2. Br J Pharmacol 165:2167-2177.

Caterina MJ, Schumacher MA, Tominaga M, Rosen TA, Levine JD, Julius D (1997) The capsaicin receptor: a heat-activated ion channel in the pain pathway. Nature 389:816-824.

Caterina MJ, Leffler A, Malmberg AB, Martin WJ, Trafton J, Petersen-Zeitz KR, Koltzenburg M, Basbaum AI, Julius D (2000) Impaired nociception and pain sensation in mice lacking the capsaicin receptor. Science 288:306-313.

Chalgeri A, Tan HS (1993) Assay of citrate in pharmaceutical matrices by indirect photometric liquid chromatography. J Pharm Biomed Anal 11:353-359.

Chen CC, England S, Akopian AN, Wood JN (1998) A sensory neuron-specific, proton-gated ion channel. Proc Natl Acad Sci U S A 95:1024010245.

Chen CC, Zimmer A, Sun WH, Hall J, Brownstein MJ, Zimmer A (2002) A role for ASIC3 in the modulation of high-intensity pain stimuli. Proc Natl Acad Sci U S A 99:8992-8997.

Collier HO, Dinneen LC, Johnson CA, Schneider C (1968) The abdominal constriction response and its suppression by analgesic drugs in the mouse. Br J Pharmacol Chemother 32:295-310.

Coryell MW, Wunsch AM, Haenfler JM, Allen JE, McBride JL, Davidson BL, Wemmie JA (2008) Restoring acid-sensing ion channel-1a in the amygdala of knock-out mice rescues fear memory but not unconditioned fear responses. J Neurosci 28:13738-13741.

Diochot S, Baron A, Rash LD, Deval E, Escoubas P, Scarzello S, Salinas M, Lazdunski M (2004) A new sea anemone peptide, APETx2, inhibits ASIC3, a major acid-sensitive channel in sensory neurons. EMBO J 23:1516-1525.

Diochot S, Baron A, Salinas M, Douguet D, Scarzello S, Dabert-Gay AS, Debayle D, Friend V, Alloui A, Lazdunski M, Lingueglia E (2012) Black mamba venom peptides target acid-sensing ion channels to abolish pain. Nature 490:552-555.

Duan B, Wang YZ, Yang T, Chu XP, Yu Y, Huang Y, Cao H, Hansen J, Simon RP, Zhu MX, Xiong ZG, Xu TL (2011) Extracellular spermine exacerbates ischemic neuronal injury through sensitization of ASICla channels to extracellular acidosis. J Neurosci 31:2101-2112.

Escoubas P, De Weille JR, Lecoq A, Diochot S, Waldmann R, Champigny G, Moinier D, Ménez A, Lazdunski M (2000) Isolation of a tarantula toxin specific for a class of proton-gated $\mathrm{Na}+$ channels. J Biol Chem 275:25116-25121.

Ettaiche M, Guy N, Hofman P, Lazdunski M, Waldmann R (2004) Acidsensing ion channel 2 is important for retinal function and protects against light-induced retinal degeneration. J Neurosci 24:1005-1012.

Frenken LA, van Lier HJ, Jordans JG, Leunissen KM, van Leusen R, Verstappen VM, Koene RA (1993) Identification of the component part in an epoetin alfa preparation that causes pain after subcutaneous injection. Am J Kidney Dis 22:553-556.

Friese MA, Craner MJ, Etzensperger R, Vergo S, Wemmie JA, Welsh MJ, Vincent A, Fugger L (2007) Acid-sensing ion channel-1 contributes to axonal degeneration in autoimmune inflammation of the central nervous system. Nat Med 13:1483-1489.

Furst DE, Schiff MH, Fleischmann RM, Strand V, Birbara CA, Compagnone D, Fischkoff SA, Chartash EK (2003) Adalimumab, a fully human antitumor necrosis factor-alpha monoclonal antibody, and concomitant standard antirheumatic therapy for the treatment of rheumatoid arthritis: results of STAR (Safety Trial of Adalimumab in Rheumatoid Arthritis). J Rheumatol 30:2563-2571.

García-Añoveros J, Derfler B, Neville-Golden J, Hyman BT, Corey DP (1997) $\mathrm{BNaC} 1$ and $\mathrm{BNaC} 2$ constitute a new family of human neuronal sodium channels related to degenerins and epithelial sodium channels. Proc Natl Acad Sci U S A 94:1459-1464.

González-Cano R, Montilla-García A, Ruiz-Cantero MC, Bravo-Caparrós I, Tejada MA, Nieto FR, Cobos EJ (2020) The search for translational pain outcomes to refine analgesic development: where did we come from and where are we going? Neurosci Biobehav Rev 113:238-261.

Greenwald I (1938) The dissociation of some calcium salts. J Biol Chem 124:437-452.

Gründer S, Geissler HS, Bässler EL, Ruppersberg JP (2000) A new member of acid-sensing ion channels from pituitary gland. Neuroreport 11:16071611.

Gunthorpe MJ, Smith GD, Davis JB, Randall AD (2001) Characterisation of a human acid-sensing ion channel (hASICla) endogenously expressed in HEK293 cells. Pflugers Arch 442:668-674.

He W, Miao FJ, Lin DC, Schwandner RT, Wang Z, Gao J, Chen JL, Tian H, Ling L (2004) Citric acid cycle intermediates as ligands for orphan G-protein-coupled receptors. Nature 429:188-193.

Hunskaar S, Fasmer OB, Hole K (1985) Formalin test in mice, a useful technique for evaluating mild analgesics. J Neurosci methods 14:69-76.

Ikeuchi M, Kolker SJ, Burnes LA, Walder RY, Sluka KA (2008) Role of ASIC3 in the primary and secondary hyperalgesia produced by joint inflammation in mice. Pain 137:662-669.

Immke DC, McCleskey EW (2003) Protons open acid-sensing ion channels by catalyzing relief of $\mathrm{Ca} 2+$ blockade. Neuron 37:75-84.

Issberner U, Reeh PW, Steen KH (1996) Pain due to tissue acidosis: a mechanism for inflammatory and ischemic myalgia? Neurosci Lett 208:191194.

Joeres N, Augustinowski K, Neuhof A, Assmann M, Gründer S (2016) Functional and pharmacological characterization of two different ASIC1a/2a heteromers reveals their sensitivity to the spider toxin PcTx1. Sci Rep 6:27647.

Jones NG, Slater R, Cadiou H, McNaughton P, McMahon SB (2004) Acidinduced pain and its modulation in humans. J Neurosci 24:10974-10979.

Joseph NR (1946) The dissociation constants of organic calcium complexes. J Biol Chem 164:529-541.

Keystone EC, Kavanaugh AF, Sharp JT, Tannenbaum H, Hua Y, Teoh LS, Fischkoff SA, Chartash EK (2004) Radiographic, clinical, and functional outcomes of treatment with adalimumab (a human anti-tumor necrosis factor monoclonal antibody) in patients with active rheumatoid arthritis receiving concomitant methotrexate therapy: a randomized, placebo-controlled, 52-week trial. Arthritis Rheum 50:1400-1411.

Laursen T, Hansen B, Fisker S (2006) Pain perception after subcutaneous injections of media containing different buffers. Basic Clin Pharmacol Toxicol 98:218-221.

Le Bars D, Gozariu M, Cadden SW (2001) Animal models of nociception. Pharmacol Rev 53:597-652.

Li WG, Yu Y, Huang C, Cao H, Xu TL (2011) Nonproton ligand sensing domain is required for paradoxical stimulation of acid-sensing ion channel 3 (ASIC3) channels by amiloride. J Biol Chem 286:42635-42646.

Lin SH, Cheng YR, Banks RW, Min MY, Bewick GS, Chen CC (2016) Evidence for the involvement of ASIC3 in sensory mechanotransduction in proprioceptors. Nat Commun 7:11460.

Lingueglia E, de Weille JR, Bassilana F, Heurteaux C, Sakai H, Waldmann R, Lazdunski M (1997) A modulatory subunit of acid sensing ion channels in brain and dorsal root ganglion cells. J Biol Chem 272:29778-29783.

Liu Y, Hagan R, Schoellerman J (2018) Dual actions of Psalmotoxin at ASIC1a and ASIC2a heteromeric channels (ASIC1a/2a). Sci Rep 8:7179.

Nash P, Vanhoof J, Hall S, Arulmani U, Tarzynski-Potempa R, Unnebrink K, Payne AN, Cividino A (2016) Randomized crossover comparison of injection site pain with $40 \mathrm{mg} / 0.4$ or $0.8 \mathrm{~mL}$ formulations of adalimumab in patients with rheumatoid arthritis. Rheumatol Ther 3:257-270.

Pan HL, Longhurst JC, Eisenach JC, Chen SR (1999) Role of protons in activation of cardiac sympathetic C-fibre afferents during ischaemia in cats. J Physiol 518:857-866.

Paukert M, Babini E, Pusch M, Gründer S (2004) Identification of the Ca2+ blocking site of acid-sensing ion channel (ASIC) 1: implications for channel gating. J Gen Physiol 124:383-394. 
Peng BG, Ahmad S, Chen S, Chen P, Price MP, Lin X (2004) Acid-sensing ion channel 2 contributes a major component to acid-evoked excitatory responses in spiral ganglion neurons and plays a role in noise susceptibility of mice. J Neurosci 24:10167-10175.

Price MP, Snyder PM, Welsh MJ (1996) Cloning and expression of a novel human brain Na+ channel. J Biol Chem 271:7879-7882.

Price MP, Lewin GR, McIlwrath SL, Cheng C, Xie J, Heppenstall PA, Stucky CL, Mannsfeldt AG, Brennan TJ, Drummond HA, Qiao J, Benson CJ, Tarr DE, Hrstka RF, Yang B, Williamson RA, Welsh MJ (2000) The mammalian sodium channel BNC1 is required for normal touch sensation. Nature 407:1007-1011.

Price MP, McIlwrath SL, Xie J, Cheng C, Qiao J, Tarr DE, Sluka KA, Brennan TJ, Lewin GR, Welsh MJ (2001) The DRASIC cation channel contributes to the detection of cutaneous touch and acid stimuli in mice. Neuron 32:1071-1083.

Pygall SR, Kujawinski S, Timmins P, Melia CD (2009) Mechanisms of drug release in citrate buffered HPMC matrices. Int J Pharm 370:110-120.

Roza C, Puel JL, Kress M, Baron A, Diochot S, Lazdunski M, Waldmann R (2004) Knockout of the ASIC2 channel in mice does not impair cutaneous mechanosensation, visceral mechanonociception and hearing. J Physiol 558:659-669.

Sherwood TW, Lee KG, Gormley MG, Askwith CC (2011) Heteromeric acid-sensing ion channels (ASICs) composed of ASIC2b and ASIC1a display novel channel properties and contribute to acidosis-induced neuronal death. J Neurosci 31:9723-9734.

Sluka KA, Price MP, Breese NM, Stucky CL, Wemmie JA, Welsh MJ (2003) Chronic hyperalgesia induced by repeated acid injections in muscle is abolished by the loss of ASIC3, but not ASIC1. Pain 106:229-239.

Sluka KA, Radhakrishnan R, Benson CJ, Eshcol JO, Price MP, Babinski K, Audette KM, Yeomans DC, Wilson SP (2007) ASIC3 in muscle mediates mechanical, but not heat, hyperalgesia associated with muscle inflammation. Pain 129:102-112.

Staniland AA, McMahon SB (2009) Mice lacking acid-sensing ion channels (ASIC) 1 or 2, but not ASIC3, show increased pain behaviour in the formalin test. Eur J Pain 13:554-563.

Steen KH, Reeh PW (1993) Sustained graded pain and hyperalgesia from harmless experimental tissue acidosis in human skin. Neurosc Lett 154:113-116.

Steen KH, Issberner U, Reeh PW (1995) Pain due to experimental acidosis in human skin: evidence for non-adapting nociceptor excitation. Neuroscience letters 199:29-32.

Tominaga M, Caterina MJ, Malmberg AB, Rosen TA, Gilbert H, Skinner K, Raumann BE, Basbaum AI, Julius D (1998) The cloned capsaicin receptor integrates multiple pain-producing stimuli. Neuron 21:531-543.

Ugawa S, Ueda T, Ishida Y, Nishigaki M, Shibata Y, Shimada S (2002) Amiloride-blockable acid-sensing ion channels are leading acid sensors expressed in human nociceptors. J Clin Invest 110:1185-1190.

van de Putte LB, Atkins C, Malaise M, Sany J, Russell AS, van Riel PL, Settas L, Bijlsma JW, Todesco S, Dougados M, Nash P, Emery P, Walter N, Kaul M, Fischkoff S, Kupper H (2004) Efficacy and safety of adalimumab as monotherapy in patients with rheumatoid arthritis for whom previous disease modifying antirheumatic drug treatment has failed. Ann Rheum Dis 63:508-516.

Veys N, Dhondt A, Lameire N (1998) Pain at the injection site of subcutaneously administered erythropoietin: phosphate-buffered epoetin alpha compared to citrate-buffered epoetin alpha and epoetin beta. Clin Nephrol 49:41-44.

Walder RY, Rasmussen LA, Rainier JD, Light AR, Wemmie JA, Sluka KA (2010) ASIC1 and ASIC3 play different roles in the development of hyperalgesia after inflammatory muscle injury. J Pain 11:210-218.

Waldmann R, Champigny G, Voilley N, Lauritzen I, Lazdunski M (1996) The mammalian degenerin MDEG, an amiloride-sensitive cation channel activated by mutations causing neurodegeneration in Caenorhabditis elegans. J Biol Chem 271:10433-10436.
Waldmann R, Champigny G, Bassilana F, Heurteaux C, Lazdunski M (1997a) A proton-gated cation channel involved in acid-sensing. Nature 386:173-177.

Waldmann R, Bassilana F, de Weille J, Champigny G, Heurteaux C, Lazdunski M (1997b) Molecular cloning of a non-inactivating protongated $\mathrm{Na}+$ channel specific for sensory neurons. J Biol Chem 272:2097520978.

Walser M (1961) Ion association. v. dissociation constants for complexes of citrate with sodium, potassium, calcium, and magnesium ions. J Phys Chem 65:159-161.

Wang X, Li WG, Yu Y, Xiao X, Cheng J, Zeng WZ, Peng Z, Xi Zhu M, Xu TL (2013) Serotonin facilitates peripheral pain sensitivity in a manner that depends on the nonproton ligand sensing domain of ASIC3 channel. J Neurosci 33:4265-4279.

Wemmie JA, Chen J, Askwith CC, Hruska-Hageman AM, Price MP, Nolan BC, Yoder PG, Lamani E, Hoshi T, Freeman JH Jr, Welsh MJ (2002) The acid-activated ion channel ASIC contributes to synaptic plasticity, learning, and memory. Neuron 34:463-477.

Wemmie JA, Askwith CC, Lamani E, Cassell MD, Freeman JH Jr, Welsh MJ (2003) Acid-sensing ion channel 1 is localized in brain regions with high synaptic density and contributes to fear conditioning. J Neurosci 23:5496-5502.

Witkin LB, Heubner CF, Galdi F, O’Keefe E, Spitaletta P, Plummer AJ (1961) Pharmacology of 2-amino-indane hydrochloride (Su-8629): a potent non-narcotic analgesic. J Pharmacol Exp Ther 133:400-408.

Woo YC, Park SS, Subieta AR, Brennan TJ (2004) Changes in tissue pH and temperature after incision indicate acidosis may contribute to postoperative pain. Anesthesiology 101:468-475.

Wu PY, Huang YY, Chen CC, Hsu TT, Lin YC, Weng JY, Chien TC, Cheng IH, Lien CC (2013) Acid-sensing ion channel-1a is not required for normal hippocampal LTP and spatial memory. J Neurosci 33:1828-1832.

Xiong ZG, Zhu XM, Chu XP, Minami M, Hey J, Wei WL, MacDonald JF, Wemmie JA, Price MP, Welsh MJ, Simon RP (2004) Neuroprotection in ischemia: blocking calcium-permeable acid-sensing ion channels. Cell 118:687-698.

Yagi J, Wenk HN, Naves LA, McCleskey EW (2006) Sustained currents through ASIC3 ion channels at the modest $\mathrm{pH}$ changes that occur during myocardial ischemia. Circ Res 99:501-509.

Yang YL, Lai TW (2020) Native expression of ASIC1a and ASIC1b human homologues in the HEK 293 cell line allows pharmacological evaluation of analgesics targeting acid sensation in humans. Neuroreport 31:865870.

Yen YT, Tu PH, Chen CJ, Lin YW, Hsieh ST, Chen CC (2009) Role of acidsensing ion channel 3 in sub-acute-phase inflammation. Mol Pain 5:1.

Yu AW, Leung CB, Li PK, Lui SF, Lai KN (1998) Pain perception following subcutaneous injections of citrate-buffered and phosphate-buffered epoetin alpha. Int J Artif Organs 21:341-343.

Zha XM, Costa V, Harding AM, Reznikov L, Benson CJ, Welsh MJ (2009) ASIC2 subunits target acid-sensing ion channels to the synapse via an association with PSD-95. J Neurosci 29:8438-8446.

Zhang P, Sigworth FJ, Canessa CM (2006) Gating of acid-sensitive ion channel-1: release of $\mathrm{Ca} 2+$ block vs. allosteric mechanism. J Gen Physiol 127:109-117.

Ziemann AE, Schnizler MK, Albert GW, Severson MA, Howard MA 3rd, Welsh MJ, Wemmie JA (2008) Seizure termination by acidosis depends on ASIC1a. Nat Neurosci 11:816-822.

Ziemann AE, Allen JE, Dahdaleh NS, Drebot II, Coryell MW, Wunsch AM, Lynch CM, Faraci FM, Howard MA 3rd, Welsh MJ, Wemmie JA (2009) The amygdala is a chemosensor that detects carbon dioxide and acidosis to elicit fear behavior. Cell 139:1012-1021.

Zuo Z, Smith RN, Chen Z, Agharkar AS, Snell HD, Huang R, Liu J, Gonzales $\mathrm{EB}$ (2018) Identification of a unique $\mathrm{Ca}(2+)$-binding site in rat acid-sensing ion channel 3. Nat Commun 9:2082. 